\title{
THE ROLE OF SEARCH ENGINE MARKETING IN SHAPING THE MOTIVATION OF SPORT BETTING IN A DEVELOPING ECONOMY
}

\author{
Ojo Kayode ${ }^{1 *}$, Worlu Rowland ${ }^{2}$, Ogunnaike Olaleke ${ }^{3}$ \\ ${ }^{1}$ Covenant University, Nigeria, E-mail: Kayode.ojo@stu.cu.edu.ng \\ ${ }^{2}$ Prof., Covenant University, Nigeria, E-mail: rowland.worlu@covenantuniversity.edu.ng \\ ${ }^{3}$ Dr., Covenant University, Nigeria, E-mail: olaleke.ogunnaike@covenantuniversity.edu.ng \\ ${ }^{*}$ Corresponding Author
}

\begin{abstract}
People in the developing countries suffer several issues ranging from poor infrastructure to poor educational system. Due to this reason, they engage and take up many ills that end up destroying the society at large. One of the ills they take up just to make ends meet is betting. People that engage in betting are called punters. Punters that engage in betting are motivated by several factors. They either want to make more money or they see betting as a way to pass time. These punters engage the use of several tools to achieve their betting goals. For them to achieve their goals of winning, punters go through a lot to educate themselves on how to bet. They engage the search engine as a tool or channel to feed their motivation to win big. In this study, search engine is seen as an internet tool punters engage with to connect to information about betting. The punters use search engine to connect themselves with several blogs and portals to educate themselves on how betting works. The main objective of this study is to determine the role search engine marketing plays in shaping the motivation of punters in developing economies. A quantitative research method was used in this work. The study adopted a descriptive approach with focus of describing the relationship between search engine marketing and the motivation of punters. Six hundred copies of questionnaires were distributed to active punters, five hundred and fifty-four were returned. The result gotten from the field sheds light on the role search engine marketing plays in motivating punters. In the course of the study, it was discovered that people that engage with sport betting usually use the search engine to get whatever information they need in order for them to achieve their betting goals. This is very important because it shows that part of a punters' process in achieving his goals is to search for information necessary in whatever way or form. The study concludes that search engine plays an important role in aiding punters, as a matter of fact, search engine is one of the first place punters visit whenever they want to place bets online.
\end{abstract}

Keywords: Economic Motivation, Hedonic Motivation, Motivation, Search engine, Search engine marketing, Symbolic Motivation

\section{INTRODUCTION}

The dramatic change in the global e-commerce market has been enormous. People can now access products and services at the comfort of their rooms. Technology has changed the way people interact with 
their environments. Technology has also transformed the business environment used to be like to a place people from all over the world can carry out their businesses (Agboola, et al., 2017; Agboola, et al., 2019). The internet in particular has been able to connect the whole world. Information about every one or everything is accessible through the use of a mobile device. Answers to questions are found on sites like google, Bing, among others. Search engines have made it easier for people to get whatever information they need (Zhao, Fang, Li, \& Ye, 2018). Given the speed at which the internet operates, the way and manner that people shop is now changed. There is access to reviews, product and service information and the rest. People engage in sport betting for different reasons. They either want to make money, have fun or escape from whatever they are running from. People in the developing countries suffer several issues ranging from poor infrastructure to poor educational system. Due to this reason, they engage and take up many ills that end up destroying the society at large. One of the ills they take up just to make ends meet is betting. People that engage in betting are called punters. Punters that engage in betting are motivated by several factors. They either want to make more money or they see betting as a way to pass time. These punters engage the use of several tools to achieve their betting goals. For them to achieve their goals of winning, punters go through a lot to educate themselves on how to bet. They engage the search engine as a tool or channel to feed their motivation to win big. In this study, search engine is seen as an internet tool punters engage with to connect to information about betting.

\subsection{Objective}

The main objective of this study is to determine the role search engine marketing plays in shaping the motivation of punters in developing economies. To achieve this goal, the study will employ a descriptive analysis to explain the data gotten from the respondents.

\section{LITERATURE REVIEW}

\subsection{Search Engine Marketing and Sport Betting Motivation}

Search engine marketing involves the use of paid advertisement to appear on search engine result page through the use of keywords that are bided for by the marketer (Wordstream, 2020). The emergence of the internet has created opportunities for several markets to emerge. Search engine is a place where information is stored up online. The search engine sites then crawl the internet looking for keywords that are important for users of the search engine. Google is world most used search engine with billions of users connecting online to search for necessary information about what they need. Zhao, et al, (2018) stated that overabundance of online information has created opportunities for scholars to know the implications of information searching behaviour. Anybody that has access to a mobile device can access the search engine therefore satisfying their curiosity.

In sport betting, people that engage in betting are usually referred to as punters. punters exhibit several behaviours whenever the decide to bet. One of the behaviour they exhibit is that of engaging the search engine. Several factors motivate the punters to make him or her want to engage in sport betting activities. Cotte (1997) classified these motive into three parts namely the economic motive, symbolic motive and the hedonic motive. As the name suggest, economic motive focuses on the financial needs of the punter, while the symbolic motive focusses on the punter's act of trying to make a meaning out of engaging in sport betting activities. The hedonic motive focusses on the thrill and pleasure derived from engaging in sport betting activities on a regular basis.

\section{METHODOLOGY}

A quantitative research method was used in this work. The study adopted a descriptive approach with focus of describing the relationship between search engine marketing and the motivation of punters. Six hundred copies of questionnaires were distributed to active punters, five hundred and fifty-four were returned. A cluster sampling technique was adopted given that the population of the study were divided into several clusters based on the location of the punter in the south-western part of Nigeria (a developing nation with a developing economy). The results of the data were presented in the form of a cross tabulation table gotten from SPSS. The cross tabulation table helped showed how the research participants answered questions asked on a five-scaled Likert ranking ranging from strongly agree (5) to strongly disagree (1). The cross tabulation table made it easier to understand how questions were answered.

\section{RESULTS AND DISCUSSIONS}

Given the data collected from five hundred and fifty-four respondents, several descriptive table were gotten showing the responses to questions related to search engine marketing and motive as they relate with sport 
betting.

For a more detailed understanding of how the relationship between betting search engine marketing and the motive of punters, two statements were made while the respondents were required to answer based on a scale ranging from strongly agreed which is (5) to strongly disagreed which is (1). The first statement was related to search engine marketing "I use the search engine to find sport betting websites" while the second question asked was related to economic motive of the respondents "betting is a quick way to make extra money". Below is a table showing the descriptive cross tabulation relationship of the summary of the way five hundred and fifty-four respondents answered the question. In answering the questions, it was discovered that out of 554 respondents, 218 (39.4\%) respondents strongly agreed that they use search engine to find sport betting websites and they also strongly agreed that betting is a quick way to make extra money, 142 (25.6\%) respondents agreed that they use search engine to find sport betting websites and they also agreed that betting is a quick way to make extra money. None of the respondents strongly disagreed to the use of search engine to find sport betting websites and also strongly disagreed that betting is a quick way to make extra money.

Table 1Search Engine Marketing and Economic Motive Cross-tabulation

\begin{tabular}{|c|c|c|c|c|c|c|c|c|}
\hline & \multicolumn{5}{|c|}{ Economic Motive } & \multirow[b]{2}{*}{ Total } \\
\hline & & & $\begin{array}{l}\text { Strongly } \\
\text { Disagree }\end{array}$ & Disagree & Undecided & Agree & $\begin{array}{l}\text { Strongly } \\
\text { Agree }\end{array}$ & \\
\hline \multirow{20}{*}{ SEM } & \multirow{4}{*}{$\begin{array}{l}\text { Strongly } \\
\text { Disagree }\end{array}$} & Count & 0 & 2 & 0 & 3 & 8 & 13 \\
\hline & & $\begin{array}{l}\text { \% within } \\
\text { SEM }\end{array}$ & $0.0 \%$ & $15.4 \%$ & $0.0 \%$ & $23.1 \%$ & $61.5 \%$ & $100.0 \%$ \\
\hline & & $\%$ within EM & $0.0 \%$ & $16.7 \%$ & $0.0 \%$ & $1.3 \%$ & $2.8 \%$ & $2.3 \%$ \\
\hline & & $\%$ of Total & $0.0 \%$ & $0.4 \%$ & $0.0 \%$ & $0.5 \%$ & $1.4 \%$ & $2.3 \%$ \\
\hline & \multirow{4}{*}{ Disagree } & Count & 0 & 2 & 7 & 13 & 4 & 26 \\
\hline & & $\begin{array}{l}\text { \% within } \\
\text { SEM }\end{array}$ & $0.0 \%$ & $7.7 \%$ & $26.9 \%$ & $50.0 \%$ & $15.4 \%$ & $100.0 \%$ \\
\hline & & $\%$ within EM & $0.0 \%$ & $16.7 \%$ & $43.8 \%$ & $5.7 \%$ & $1.4 \%$ & $4.7 \%$ \\
\hline & & $\%$ of Total & $0.0 \%$ & $0.4 \%$ & $1.3 \%$ & $2.3 \%$ & $0.7 \%$ & $4.7 \%$ \\
\hline & \multirow{4}{*}{$\begin{array}{c}\text { Undecide } \\
\text { d }\end{array}$} & Count & 1 & 0 & 0 & 5 & 2 & 8 \\
\hline & & $\begin{array}{l}\text { \% within } \\
\text { SEM }\end{array}$ & $12.5 \%$ & $0.0 \%$ & $0.0 \%$ & $62.5 \%$ & $25.0 \%$ & $100.0 \%$ \\
\hline & & $\%$ within EM & $11.1 \%$ & $0.0 \%$ & $0.0 \%$ & $2.2 \%$ & $0.7 \%$ & $1.4 \%$ \\
\hline & & $\%$ of Total & $0.2 \%$ & $0.0 \%$ & $0.0 \%$ & $0.9 \%$ & $0.4 \%$ & $1.4 \%$ \\
\hline & \multirow{4}{*}{ Agree } & Count & 4 & 6 & 1 & 65 & 57 & 133 \\
\hline & & $\begin{array}{l}\text { \% within } \\
\text { SEM }\end{array}$ & $3.0 \%$ & $4.5 \%$ & $0.8 \%$ & $48.9 \%$ & $42.9 \%$ & $100.0 \%$ \\
\hline & & $\%$ within EM & $44.4 \%$ & $50.0 \%$ & $6.3 \%$ & $28.5 \%$ & $19.7 \%$ & $24.0 \%$ \\
\hline & & $\%$ of Total & $0.7 \%$ & $1.1 \%$ & $0.2 \%$ & $11.7 \%$ & $10.3 \%$ & $24.0 \%$ \\
\hline & \multirow{4}{*}{$\begin{array}{l}\text { Strongly } \\
\text { Agree }\end{array}$} & Count & 4 & 2 & 8 & 142 & 218 & 374 \\
\hline & & $\begin{array}{l}\text { \% within } \\
\text { SEM }\end{array}$ & $1.1 \%$ & $0.5 \%$ & $2.1 \%$ & $38.0 \%$ & $58.3 \%$ & $100.0 \%$ \\
\hline & & \% within EM & $44.4 \%$ & $16.7 \%$ & $50.0 \%$ & $62.3 \%$ & $75.4 \%$ & $67.5 \%$ \\
\hline & & $\%$ of Total & $0.7 \%$ & $0.4 \%$ & $1.4 \%$ & $25.6 \%$ & $39.4 \%$ & $67.5 \%$ \\
\hline \multirow{4}{*}{\multicolumn{2}{|c|}{ Total }} & Count & 9 & 12 & 16 & 228 & 289 & 554 \\
\hline & & $\begin{array}{l}\text { \% within } \\
\text { SEM }\end{array}$ & $1.6 \%$ & $2.2 \%$ & $2.9 \%$ & $41.2 \%$ & $52.2 \%$ & $100.0 \%$ \\
\hline & & $\%$ within EM & $100.0 \%$ & $100.0 \%$ & $100.0 \%$ & $100.0 \%$ & $100.0 \%$ & $100.0 \%$ \\
\hline & & $\%$ of Total & $1.6 \%$ & $2.2 \%$ & $2.9 \%$ & $41.2 \%$ & $52.2 \%$ & $100.0 \%$ \\
\hline
\end{tabular}

Source: Result of Field Survey (2020)

For a better understanding of how the relationship between betting search engine marketing and the motive of punters, two statements were made while the respondents were required to answer based on a scale ranging from strongly agreed which is (5) to strongly disagreed which is (1). The first statement was related to search engine marketing "I use the search engine to carry out research on teams I want to place bets on" while the second question asked was related to economic motive of the respondents "the payout from betting 
is worth the effort I put into betting". Below is a table showing the descriptive cross tabulation relationship of the summary of the way five hundred and fifty-four respondents answered the question. In answering the questions, it was discovered that out of 554 respondents, $142(25.6 \%)$ respondents strongly agreed that they use the search engine to carry out research on teams they want to place bets on and they also strongly agreed that the payout from betting is worth the effort I put into betting, $114(20.6 \%)$ respondents agreed that they use the search engine to carry out research on teams they want to place bets on and they also agreed that the payout from betting is worth the effort I put into betting. None of the respondents strongly disagreed to the use of search engine to carry out research on teams they want to place bets on and they also strongly disagreed that the payout from betting is worth the effort I put into betting.

Table 2 Search Engine Marketing and Economic Motive Crosstabulation

\begin{tabular}{|c|c|c|c|c|c|c|c|c|}
\hline & \multicolumn{5}{|c|}{ EM1 } & \multirow[b]{2}{*}{ Total } \\
\hline & & & $\begin{array}{l}\text { Strongly } \\
\text { Disagree }\end{array}$ & Disagree & $\begin{array}{c}\text { Undecide } \\
\text { d }\end{array}$ & Agree & $\begin{array}{l}\text { Strongly } \\
\text { Agree }\end{array}$ & \\
\hline \multirow{20}{*}{ SEM1 } & \multirow{4}{*}{$\begin{array}{l}\text { Strongly } \\
\text { Disagree }\end{array}$} & Count & 0 & 1 & 0 & 3 & 7 & 11 \\
\hline & & $\begin{array}{l}\text { \% within } \\
\text { SEM1 }\end{array}$ & $0.0 \%$ & $9.1 \%$ & $0.0 \%$ & $27.3 \%$ & $63.6 \%$ & $100.0 \%$ \\
\hline & & \% within EM1 & $0.0 \%$ & $12.5 \%$ & $0.0 \%$ & $1.2 \%$ & $2.7 \%$ & $2.0 \%$ \\
\hline & & $\%$ of Total & $0.0 \%$ & $0.2 \%$ & $0.0 \%$ & $0.5 \%$ & $1.3 \%$ & $2.0 \%$ \\
\hline & \multirow{4}{*}{ Disagree } & Count & 1 & 0 & 2 & 6 & 5 & 14 \\
\hline & & $\begin{array}{l}\text { \% within } \\
\text { SEM1 }\end{array}$ & $7.1 \%$ & $0.0 \%$ & $14.3 \%$ & $42.9 \%$ & $35.7 \%$ & $100.0 \%$ \\
\hline & & \% within EM1 & $6.3 \%$ & $0.0 \%$ & $8.0 \%$ & $2.4 \%$ & $2.0 \%$ & $2.5 \%$ \\
\hline & & $\%$ of Total & $0.2 \%$ & $0.0 \%$ & $0.4 \%$ & $1.1 \%$ & $0.9 \%$ & $2.5 \%$ \\
\hline & \multirow{4}{*}{ Undecided } & Count & 1 & 2 & 2 & 12 & 10 & 27 \\
\hline & & $\begin{array}{l}\text { \% within } \\
\text { SEM1 }\end{array}$ & $3.7 \%$ & $7.4 \%$ & $7.4 \%$ & $44.4 \%$ & $37.0 \%$ & $100.0 \%$ \\
\hline & & \% within EM1 & $6.3 \%$ & $25.0 \%$ & $8.0 \%$ & $4.8 \%$ & $3.9 \%$ & $4.9 \%$ \\
\hline & & $\%$ of Total & $0.2 \%$ & $0.4 \%$ & $0.4 \%$ & $2.2 \%$ & $1.8 \%$ & $4.9 \%$ \\
\hline & \multirow{4}{*}{ Agree } & Count & 11 & 4 & 11 & 114 & 92 & 232 \\
\hline & & $\begin{array}{l}\text { \% within } \\
\text { SEM1 }\end{array}$ & $4.7 \%$ & $1.7 \%$ & $4.7 \%$ & $49.1 \%$ & $39.7 \%$ & $100.0 \%$ \\
\hline & & \% within EM1 & $68.8 \%$ & $50.0 \%$ & $44.0 \%$ & $45.8 \%$ & $35.9 \%$ & $41.9 \%$ \\
\hline & & $\%$ of Total & $2.0 \%$ & $0.7 \%$ & $2.0 \%$ & $20.6 \%$ & $16.6 \%$ & $41.9 \%$ \\
\hline & \multirow{4}{*}{$\begin{array}{l}\text { Strongly } \\
\text { Agree }\end{array}$} & Count & 3 & 1 & 10 & 114 & 142 & 270 \\
\hline & & $\begin{array}{l}\text { \% within } \\
\text { SEM1 }\end{array}$ & $1.1 \%$ & $0.4 \%$ & $3.7 \%$ & $42.2 \%$ & $52.6 \%$ & $100.0 \%$ \\
\hline & & \% within EM1 & $18.8 \%$ & $12.5 \%$ & $40.0 \%$ & $45.8 \%$ & $55.5 \%$ & $48.7 \%$ \\
\hline & & $\%$ of Total & $0.5 \%$ & $0.2 \%$ & $1.8 \%$ & $20.6 \%$ & $25.6 \%$ & $48.7 \%$ \\
\hline \multirow{4}{*}{\multicolumn{2}{|c|}{ Total }} & Count & 16 & 8 & 25 & 249 & 256 & 554 \\
\hline & & $\begin{array}{l}\text { \% within } \\
\text { SEM1 }\end{array}$ & $2.9 \%$ & $1.4 \%$ & $4.5 \%$ & $44.9 \%$ & $46.2 \%$ & $100.0 \%$ \\
\hline & & \% within EM1 & $100.0 \%$ & $100.0 \%$ & $100.0 \%$ & $100.0 \%$ & $100.0 \%$ & $100.0 \%$ \\
\hline & & $\%$ of Total & $2.9 \%$ & $1.4 \%$ & $4.5 \%$ & $44.9 \%$ & $46.2 \%$ & $100.0 \%$ \\
\hline
\end{tabular}

Source: Result of Field Survey (2020)

For a more detailed understanding of how the relationship between betting search engine marketing and the motive of punters, two statements were made while the respondents were required to answer based on a scale ranging from strongly agreed which is (5) to strongly disagreed which is (1). The first statement was related to search engine marketing "I use the search engine to find the best games to bet on" while the second question asked was related to hedonic motive of the respondents "betting is an exciting enjoyable pastime". Below is a table showing the descriptive cross tabulation relationship of the summary of the way five hundred and fifty-four respondents answered the question. In answering the questions, it was discovered that out of 554 respondents, $118(21.3 \%)$ respondents strongly agreed that they use search engine to find to find the best games to bet on and they also strongly agreed that betting is an exciting enjoyable pastime, 131 $(23.6 \%)$ respondents agreed that they use search engine to find to find the best games to bet on and they 
also agreed that betting is an exciting enjoyable pastime. $2(0.4 \%)$ of the total respondents strongly disagreed that they use search engine to find to find the best games to bet on and they also strongly disagreed that betting is an exciting enjoyable pastime.

Table 3 Search Engine Marketing and Hedonic Motive Cross-tabulation

\begin{tabular}{|c|c|c|c|c|c|c|c|c|}
\hline & \multicolumn{5}{|c|}{$\mathrm{HM}$} & \multirow[b]{2}{*}{ Total } \\
\hline & & & $\begin{array}{l}\text { Strongly } \\
\text { Disagree }\end{array}$ & $\begin{array}{c}\text { Disagre } \\
\mathrm{e}\end{array}$ & $\begin{array}{c}\text { Undecide } \\
\mathrm{d}\end{array}$ & Agree & $\begin{array}{c}\text { Strongly } \\
\text { Agree }\end{array}$ & \\
\hline \multirow{20}{*}{ SEM2 } & \multirow{4}{*}{$\begin{array}{l}\text { Strongly } \\
\text { Disagree }\end{array}$} & Count & 2 & 1 & 2 & 11 & 18 & 34 \\
\hline & & $\begin{array}{l}\text { \% within } \\
\text { SEM2 }\end{array}$ & $5.9 \%$ & $2.9 \%$ & $5.9 \%$ & $32.4 \%$ & $52.9 \%$ & $100.0 \%$ \\
\hline & & \% within $\mathrm{HM}$ & $14.3 \%$ & $5.3 \%$ & $11.1 \%$ & $3.8 \%$ & $8.5 \%$ & $6.1 \%$ \\
\hline & & $\%$ of Total & $0.4 \%$ & $0.2 \%$ & $0.4 \%$ & $2.0 \%$ & $3.2 \%$ & $6.1 \%$ \\
\hline & \multirow{4}{*}{ Disagree } & Count & 2 & 7 & 5 & 16 & 13 & 43 \\
\hline & & $\begin{array}{l}\text { \% within } \\
\text { SEM2 }\end{array}$ & $4.7 \%$ & $16.3 \%$ & $11.6 \%$ & $37.2 \%$ & $30.2 \%$ & $100.0 \%$ \\
\hline & & \% within HM & $14.3 \%$ & $36.8 \%$ & $27.8 \%$ & $5.5 \%$ & $6.2 \%$ & $7.8 \%$ \\
\hline & & $\%$ of Total & $0.4 \%$ & $1.3 \%$ & $0.9 \%$ & $2.9 \%$ & $2.3 \%$ & $7.8 \%$ \\
\hline & \multirow{4}{*}{$\begin{array}{l}\text { Undecid } \\
\text { ed }\end{array}$} & Count & 2 & 2 & 3 & 12 & 23 & 42 \\
\hline & & $\begin{array}{l}\text { \% within } \\
\text { SEM2 }\end{array}$ & $4.8 \%$ & $4.8 \%$ & $7.1 \%$ & $28.6 \%$ & $54.8 \%$ & $100.0 \%$ \\
\hline & & \% within HM & $14.3 \%$ & $10.5 \%$ & $16.7 \%$ & $4.1 \%$ & $10.9 \%$ & $7.6 \%$ \\
\hline & & $\%$ of Total & $0.4 \%$ & $0.4 \%$ & $0.5 \%$ & $2.2 \%$ & $4.2 \%$ & $7.6 \%$ \\
\hline & \multirow{4}{*}{ Agree } & Count & 2 & 6 & 4 & 131 & 39 & 182 \\
\hline & & $\begin{array}{c}\text { \% within } \\
\text { SEM2 }\end{array}$ & $1.1 \%$ & $3.3 \%$ & $2.2 \%$ & $72.0 \%$ & $21.4 \%$ & $100.0 \%$ \\
\hline & & \% within $\mathrm{HM}$ & $14.3 \%$ & $31.6 \%$ & $22.2 \%$ & $44.9 \%$ & $18.5 \%$ & $32.9 \%$ \\
\hline & & $\%$ of Total & $0.4 \%$ & $1.1 \%$ & $0.7 \%$ & $23.6 \%$ & $7.0 \%$ & $32.9 \%$ \\
\hline & \multirow{4}{*}{$\begin{array}{l}\text { Strongly } \\
\text { Agree }\end{array}$} & Count & 6 & 3 & 4 & 122 & 118 & 253 \\
\hline & & $\begin{array}{l}\text { \% within } \\
\text { SEM2 }\end{array}$ & $2.4 \%$ & $1.2 \%$ & $1.6 \%$ & $48.2 \%$ & $46.6 \%$ & $100.0 \%$ \\
\hline & & \% within $\mathrm{HM}$ & $42.9 \%$ & $15.8 \%$ & $22.2 \%$ & $41.8 \%$ & $55.9 \%$ & $45.7 \%$ \\
\hline & & $\%$ of Total & $1.1 \%$ & $0.5 \%$ & $0.7 \%$ & $22.0 \%$ & $21.3 \%$ & $45.7 \%$ \\
\hline \multirow{4}{*}{\multicolumn{2}{|c|}{ Total }} & Count & 14 & 19 & 18 & 292 & 211 & 554 \\
\hline & & $\begin{array}{l}\text { \% within } \\
\text { SEM2 }\end{array}$ & $2.5 \%$ & $3.4 \%$ & $3.2 \%$ & $52.7 \%$ & $38.1 \%$ & $100.0 \%$ \\
\hline & & $\%$ within HM & $100.0 \%$ & $100.0 \%$ & $100.0 \%$ & $100.0 \%$ & $100.0 \%$ & $100.0 \%$ \\
\hline & & $\%$ of Total & $2.5 \%$ & $3.4 \%$ & $3.2 \%$ & $52.7 \%$ & $38.1 \%$ & $100.0 \%$ \\
\hline
\end{tabular}

Source: Result of Field Survey (2020)

For a more detailed understanding of how the relationship between betting search engine marketing and the motive of punters, two statements were made while the respondents were required to answer based on a scale ranging from strongly agreed which is (5) to strongly disagreed which is (1). The first statement was related to search engine marketing "I use the search engine to find best prediction websites" while the second question asked was related to symbolic motive of the respondents "betting is a form of escape from personal problems and worries". Below is a table showing the descriptive cross tabulation relationship of the summary of the way five hundred and fifty-four respondents answered the question. In answering the questions, it was discovered that out of 554 respondents, $113(20.4 \%)$ respondents strongly agreed that they use the search engine to find best prediction websites and they also strongly agreed that betting is a form of escape from personal problems and worries, $82(14.8 \%)$ respondents agreed that they use the search engine to find best prediction websites and they also agreed that betting is a form of escape from personal problems and worries. $9(1.6 \%)$ of the respondents strongly disagreed that they use the search engine to find best prediction websites and they also strongly disagreed that betting is a form of escape from personal problems and worries. 
Table 4 Search Engine Marketing and Symbolic Motive Cross-tabulation

\begin{tabular}{|c|c|c|c|c|c|c|c|c|}
\hline & \multicolumn{5}{|c|}{ SM } & \multirow[b]{2}{*}{ Total } \\
\hline & & & $\begin{array}{c}\text { Strongly } \\
\text { Disagre } \\
\text { e }\end{array}$ & $\begin{array}{c}\text { Disagre } \\
e\end{array}$ & $\begin{array}{l}\text { Undecide } \\
\text { d }\end{array}$ & Agree & $\begin{array}{c}\text { Strongly } \\
\text { Agree }\end{array}$ & \\
\hline \multirow{20}{*}{ SEM3 } & \multirow{4}{*}{ Strongly Disagree } & Count & 9 & 3 & 7 & 3 & 25 & 47 \\
\hline & & $\begin{array}{l}\text { \% within } \\
\text { SEM3 }\end{array}$ & $19.1 \%$ & $6.4 \%$ & $14.9 \%$ & $6.4 \%$ & $53.2 \%$ & $100.0 \%$ \\
\hline & & \% within SM & $11.8 \%$ & $5.8 \%$ & $24.1 \%$ & $1.5 \%$ & $12.4 \%$ & $8.5 \%$ \\
\hline & & $\%$ of Total & $1.6 \%$ & $0.5 \%$ & $1.3 \%$ & $0.5 \%$ & $4.5 \%$ & $8.5 \%$ \\
\hline & \multirow{4}{*}{ Disagree } & Count & 12 & 5 & 3 & 16 & 9 & 45 \\
\hline & & $\begin{array}{c}\text { \% within } \\
\text { SEM3 }\end{array}$ & $26.7 \%$ & $11.1 \%$ & $6.7 \%$ & $35.6 \%$ & $20.0 \%$ & $100.0 \%$ \\
\hline & & \% within SM & $15.8 \%$ & $9.6 \%$ & $10.3 \%$ & $8.2 \%$ & $4.5 \%$ & $8.1 \%$ \\
\hline & & $\%$ of Total & $2.2 \%$ & $0.9 \%$ & $0.5 \%$ & $2.9 \%$ & $1.6 \%$ & $8.1 \%$ \\
\hline & \multirow{4}{*}{ Undecided } & Count & 3 & 0 & 8 & 7 & 7 & 25 \\
\hline & & $\begin{array}{c}\text { \% within } \\
\text { SEM3 }\end{array}$ & $12.0 \%$ & $0.0 \%$ & $32.0 \%$ & $28.0 \%$ & $28.0 \%$ & $100.0 \%$ \\
\hline & & \% within SM & $3.9 \%$ & $0.0 \%$ & $27.6 \%$ & $3.6 \%$ & $3.5 \%$ & $4.5 \%$ \\
\hline & & $\%$ of Total & $0.5 \%$ & $0.0 \%$ & $1.4 \%$ & $1.3 \%$ & $1.3 \%$ & $4.5 \%$ \\
\hline & \multirow{4}{*}{ Agree } & Count & 32 & 34 & 3 & 82 & 47 & 198 \\
\hline & & $\begin{array}{c}\text { \% within } \\
\text { SEM3 }\end{array}$ & $16.2 \%$ & $17.2 \%$ & $1.5 \%$ & $41.4 \%$ & $23.7 \%$ & $100.0 \%$ \\
\hline & & \% within SM & $42.1 \%$ & $65.4 \%$ & $10.3 \%$ & $41.8 \%$ & $23.4 \%$ & $35.7 \%$ \\
\hline & & $\%$ of Total & $5.8 \%$ & $6.1 \%$ & $0.5 \%$ & $14.8 \%$ & $8.5 \%$ & $35.7 \%$ \\
\hline & \multirow{4}{*}{ Strongly Agree } & Count & 20 & 10 & 8 & 88 & 113 & 239 \\
\hline & & $\begin{array}{l}\text { \% within } \\
\text { SEM3 }\end{array}$ & $8.4 \%$ & $4.2 \%$ & $3.3 \%$ & $36.8 \%$ & $47.3 \%$ & $100.0 \%$ \\
\hline & & \% within SM & $26.3 \%$ & $19.2 \%$ & $27.6 \%$ & $44.9 \%$ & $56.2 \%$ & $43.1 \%$ \\
\hline & & $\%$ of Total & $3.6 \%$ & $1.8 \%$ & $1.4 \%$ & $15.9 \%$ & $20.4 \%$ & $43.1 \%$ \\
\hline \multirow{4}{*}{\multicolumn{2}{|c|}{ Total }} & Count & 76 & 52 & 29 & 196 & 201 & 554 \\
\hline & & $\begin{array}{l}\text { \% within } \\
\text { SEM3 }\end{array}$ & $13.7 \%$ & $9.4 \%$ & $5.2 \%$ & $35.4 \%$ & $36.3 \%$ & $100.0 \%$ \\
\hline & & \% within SM & $100.0 \%$ & $100.0 \%$ & $100.0 \%$ & $100.0 \%$ & $100.0 \%$ & $100.0 \%$ \\
\hline & & $\%$ of Total & $13.7 \%$ & $9.4 \%$ & $5.2 \%$ & $35.4 \%$ & $36.3 \%$ & $100.0 \%$ \\
\hline
\end{tabular}

Source: Result of Field Survey (2020)

\subsection{Discussion of Findings}

The result gotten from the field sheds light on the role search engine marketing plays in motivating punters. In the course of the study, it was discovered that people that engage with sport betting usually use the search engine to get whatever information they need in order for them to achieve their betting goals. This is very important because it shows that part of a punters' process in achieving his goals is to search for information necessary in whatever way or form.

The first table explains the relationship between the punters' need to make quick extra money through the use of search engine to find sport betting websites. A large majority of the respondents agreed that they use the search engine to find sport betting websites. Using the theory of prospective gratification which assumes that audience, which are the punters hers actively try to find media in a goal oriented manner to achieve whatever goal they have (Katz, Blumler, \& Gurevitch, 1973). Search engine here is seen as a media which the punters use as a portal to find information on making more money to solve whatever needs or problems they have.

The second table simply describes the relationship between the use of search engine to carry out research on the sport teams punters want to bet on and the perception of if the payout from placing bets is worth the effort and time punters put into it. From the table, it can be deduced that the majority of the respondents agreed that the effort put into sport betting is worth the pay out and that they also use search engine to carry 
out research on whatever teams they want to bet on. This means that the search engine also serves as a research tool for punters that are highly motivated to win whatever prize they have decided to win despite the efforts required to put into the betting process.

The third table describe the relationship between the use of search engine to find the best games to bet on and if betting is an enjoyable pastime for the respondents. Some punters are not motivated and driven by the money they gain from placing bets, the consider betting to be a way to have fun and relax. Most of the respondents agreed that although they want to make more money, they also enjoy the thrill involved in placing bets. This validates the findings of Cotte (1997) as regards punters seeking to have fun while placing bets.

The fourth table seeks to describe the relationship between the punters' use of search engine to look for the best betting prediction websites while at the same time using betting as a form of escape from personal problems and worries. This implies that part of the motive for placing bets is not only to win a cash prize. Some punters use it as a side distraction from the issues relating to their day to day living. Cotte (1997) referred to this type of motivation as symbolic motivation in which the punter finds meaning different from winning the cash prize when it comes to placing bets.

\section{CONCLUSION}

Since the sport betting industry has migrated online, sport betting companies have found different ways of grabbing the attention of their audience. Search engine is one of those means through which sport betting companies use. These companies tap in to the punters need for information on sport betting, the companies make sure they rank high on the search engine result pages which makes it easier for punters to find them thereby connecting to the punter's need to make more money especially for a developing nation like Nigeria. These sport betting companies also find a way to position themselves on the search engine sites through placement of ads or blog post that seems to catch the attention of sport betting audience.

This study endeavors to show the role search engine marketing plays in shaping the motivation of punters in developing economy. The search engine plays an important role in assisting punters achieve whatever goals they have. The study concludes that search engine plays an important role in aiding punters, as a matter of fact, search engine is one of the first place punters visit whenever they want to place bets online. This information is as important to the government agencies as is the sport betting industry as a whole.

\section{REFERENCES LIST}

Agboola, G. M., Blessing, A., Akinbode, A., Peters, M., \& Motilewa, D. (2017). Technology acceptance and usage: a catalyst for better performance of the 21 st century SMEs in Nigeria. Advanced Science Letters, 23(9), 9329-9333.

Agboola, M. G., Awobajo, K. A., Oluwatobi, S. O., Akinbode, M. O., Fagbohun, M. O., Esse, U. C., \& Betek, C. M. (2019, September). Effect of digitalization on the performance of commercial banks in Nigeria. In IOP Conference Series: Earth and Environmental Science (Vol. 331, No. 1, p. 012014). IOP Publishing.

Cotte, J. (1997). Chances, trances, and lots of slots: Gambling motives and consumption experiences. Journal of Leisure Research, 29(4), 380-406.

Katz, E., Blumler, J. G., \& Gurevitch, M. (1973). Uses and gratifications research. The public opinion quarterly, 37(4), 509-523.

Wordstream, (2020). Search engine marketing (SEM): What it is and How to Do it right. Retrieved from https://www.wordstream.com/search-engine-marketing, January, 2020.

Zhao, D., Fang, B., Li, H., \& Ye, Q. (2018). Google search effect on experience product sales and users' motivation to search: empirical evidence from the hotel industry. Journal of Electronic Commerce Research, 19(4), 357-369. 